\title{
Stem Cell Repair and Regeneration
}

Volume 3 
This page intentionally left blank 


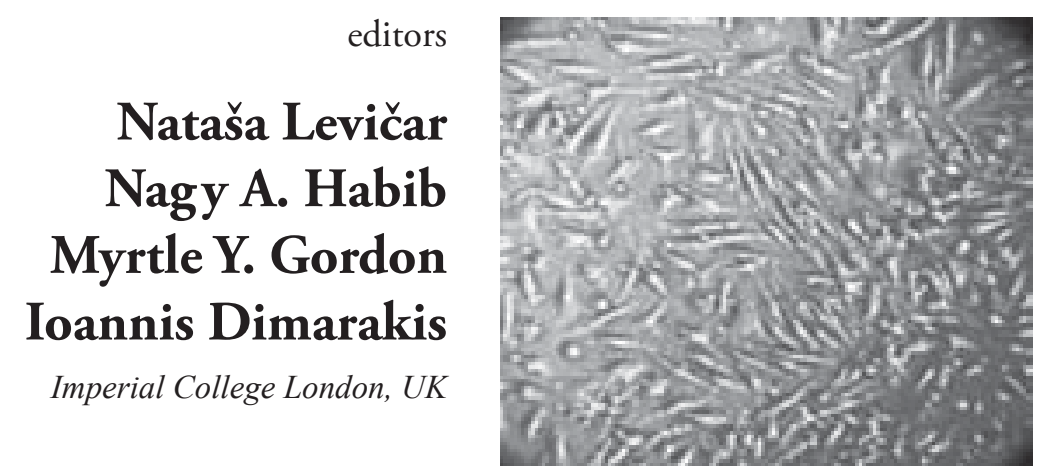

\section{Stem Cell Repair and Regeneration Volume 3}

The Hammersmith Series 3 
Published by

Imperial College Press

57 Shelton Street

Covent Garden

London WC2H 9HE

\section{Distributed by}

World Scientific Publishing Co. Pte. Ltd.

5 Toh Tuck Link, Singapore 596224

USA office: 27 Warren Street, Suite 401-402, Hackensack, NJ 07601

UK office: 57 Shelton Street, Covent Garden, London WC2H 9HE

\section{British Library Cataloguing-in-Publication Data}

A catalogue record for this book is available from the British Library.

\section{STEM CELL REPAIR AND REGENERATION \\ Volume 3}

Copyright (C) 2008 by Imperial College Press

All rights reserved. This book, or parts thereof, may not be reproduced in any form or by any means, electronic or mechanical, including photocopying, recording or any information storage and retrieval system now known or to be invented, without written permission from the Publisher.

For photocopying of material in this volume, please pay a copying fee through the Copyright Clearance Center, Inc., 222 Rosewood Drive, Danvers, MA 01923, USA. In this case permission to photocopy is not required from the publisher.

ISBN-13 978-1-86094-980-7

ISBN-10 1-86094-980-0

Typeset by Stallion Press

Email: enquiries@ stallionpress.com

Printed in Singapore. 


\section{Contents}

Contributors $\quad$ ix

Preface $\quad$ xix

Chapter 1. The Biology of Human Mesenchymal Stem Cells 1

Claire Westwood and Mark O. Clements

Chapter 2. Mesenchymal Stem Cells: From Culture to Clinic

Carl A. Gregory

Chapter 3. Stem Cell Bioprocessing for Clinical

Applications of Regenerative Medicine

Athanaslos Mantalaris, Wesley L. Randle and Julia M. Polak

Chapter 4. Defining and Overcoming the Immunological Barriers to Stem Cell Therapies

Nathan J. Robertson, Herman Waldmann and Paul J. Fairchild 
Chapter 5. Activation of the Immune System: A Corollary of Transplantation with ES Cell-Derived Tissues

Ashleigh S. Boyd, Douglas C. Wu and Kathryn J. Wood

Chapter 6. Suppression of HLA Expression by

Lentivirus-Mediated Gene Transfer of

siRNA Cassettes

Noriyuki Kasahara

Chapter 7. Cord Blood Cells for Myocardial Regeneration

Christof Stamm and Nan Ma

Chapter 8. Clinical Trials in Cardiac Stem Cell Therapy:

An Update

Ronald Kam and Ioannis Dimarakis

Chapter 9. Stem Cell Therapy in Neurodegenerative Disease

Catherine T. Flores and Myrtle Y. Gordon

Chapter 10. Adult Human Stem Cell Therapy

for Ischaemic Stroke

Deborah Williamson, Jeremy Chataway and Nagy Habib

Chapter 11. Cell Therapy in Renal Disease

H. David Humes

Chapter 12. Regenerative Medicine of the Eye: A Short Review

David T. Harris, Xianghui He, Michael Badowski and John C. Nichols

Chapter 13. A Clearer View of Stem Cells in Retinal Disease

Matthew D. Hodges, Cheryl Y. Gregory-Evans and Kevin Gregory-Evans 
Chapter 14. Limbal Epithelial Stem Cells: Biology and Therapeutic Potential

Maria Notara, Alex J. Shortt, Julie T. Daniels

Chapter 15. The Use of Mesenchymal Stem Cells for Bone and Cartilage Repair 269

Rosemary Behan, Nagy A. Habib, Scan P. F. Hughes, Myrtle Y. Gordon and Nataša Levičar

Index 
This page intentionally left blank 


\section{Contributors}

\section{Michael Badowski, BS}

Department of Immunobiology

University of Arizona

PO Box 245049

Tucson, AZ 85724, USA

Rosemary Behan, BA

Department of Biosurgery and Surgical Technology

Division of Surgery, Oncology,

Reproductive Biology and Anaesthetics (SORA)

Faculty of Medicine

Imperial College London

Hammersmith Hospital

Du Cane Rd

4N5 Commonwealth Building

London, W12 0NN, UK

\section{Ashleigh S. Boyd, D.Phil}

Transplantation Research Immunology Group

Nuffield Department of Surgery

John Radcliffe Hospital

University of Oxford

Oxford, OX3 9DS, UK 


\section{Jeremy Chataway, MA, PhD, MRCP}

Department of Neurology

St. Mary's Hospital

Praed Street, Paddington

London, W2 1NY, UK

\section{Mark O. Clements, PhD}

Wolfson Institute for Biomedical Research

University College London

The Cruciform Building, Gower Street

London, WC1E 6BT, UK

\section{Julie T. Daniels, PhD}

Director, Cells for Sight Tissue Bank, Moorfields Eye Hospital Head, Cells for Sight Transplantation and Research Programme Ocular Repair and Regeneration Biology Unit University College London Institute of Ophthalmology 11-43 Bath Street

London, EC1V 9EL, UK

\section{Ioannis Dimarakis, MRCS}

Department of Surgery

Faculty of Medicine

Imperial College London

Hammersmith Hospital

Du Cane Road

London, W12 ONN, UK

\section{Paul J. Fairchild, DPhil(Oxon)}

Sir William Dunn School of Pathology

University of Oxford

South Parks Road

Oxford, OX1 3RE, UK 


\section{Catherine T. Flores, MSc}

Department of Haematology

Investigative Science Division

Faculty of Medicine

Imperial College London

Hammersmith Hospital

Du Cane Rd

Commonwealth Building

London, W12 0NN, UK

\section{Myrtle Y. Gordon, Dsc, PhD}

Department of Haematology

Investigative Science Division

Faculty of Medicine

Imperial College London

Hammersmith Hospital

Du Cane Rd

4N5 Commonwealth Building

London, W12 0NN, UK

\section{Carl A. Gregory, PhD}

Assistant Professor in the Department of Medicine

Center for Gene Therapy

Tulane University Health Sciences Center

1430 Tulane Avenue

6th Floor JBJ Building SL99

New Orleans, LA 70112, USA

\section{Cheryl Y. Gregory-Evans, PhD}

Department of Clinical Neuroscience

Division of Neuroscience and Mental Health

Faculty of Medicine

Imperial College London

Exhibition Road

Room 107, Alexander Fleming Building

London, SW7 2AZ, UK 


\section{Kevin Gregory-Evans, MD, FRCS, FRCOphth}

Department of Clinical Neuroscience

Division of Neuroscience and Mental Health

Faculty of Medicine

Imperial College London

Charing Cross Campus

St Dunstans Road

Room 9L-07, Laboratory Block

London, W6 8RP, UK

\section{Nagy A. Habib, FRCS, MD}

Department of Biosurgery and Surgical Technology

Division of Surgery, Oncology,

Reproductive Biology and Anaesthetics (SORA)

Faculty of Medicine

Imperial College London

Hammersmith Hospital

Du Cane Rd

World of Surgery

BN1/17 B Block

London, W12 0NN, UK

\section{David T. Harris, PhD}

Department of Immunobiology

University of Arizona

PO Box 245049

Tucson, AZ 85724, USA

\section{Xianghui He, MD, PhD}

Department of Immunobiology

University of Arizona

PO Box 245049

Tucson, AZ 85724, USA 


\section{Matthew D. Hodges, PhD}

Department of Clinical Neuroscience

Division of Neuroscience and Mental Health

Faculty of Medicine

Imperial College London

Charing Cross Campus

St Dunstans Road

Room 9L-09, Laboratory Block

London, W6 8RP, UK

Sean P. F. Hughes, MD, MS, FRCS Ed (Orth), FRCS, FRCSI

Emeritus Professor Orthopaedic Surgery

Division of Surgery, Oncology,

Reproductive Biology and Anaesthetics (SORA)

Faculty of Medicine

Imperial College London

Hammersmith Hospital

Du Cane Rd

World of Surgery

BN1/17 B Block

London, W12 0NN, UK

\section{H. David Humes, MD}

Department of Internal Medicine

Division of Nephrology

University of Michigan School of Medicine

1150 W. Medical Center Drive

4520 MSRB I, SPC 5651

Ann Arbor, MI 48109, USA

\section{Ronald Kam}

Department of Surgery

Faculty of Medicine

Imperial College London

Hammersmith Hospital

Du Cane Road

London, W12 ONN, UK 


\section{Noriyuki Kasahara, MD, PhD}

Director, Vector Core and Shared Resource

UCLA CURE Digestive Disease Research Center and Jonsson Comprehensive Cancer Center

Associate Professor

Departments of Medicine and Medical and Molecular Pharmacology

David Geffen School of Medicine

University of California Los Angeles (UCLA)

675 Charles E. Young Drive South, MRL-1551

Los Angeles, CA, 90095, USA

\section{Nataša Levičar, PhD}

Department of Oncology

Division of Surgery, Oncology,

Reproductive Biology and Anaesthetics (SORA)

Faculty of Medicine

Imperial College London

Hammersmith Hospital

Du Cane Rd

World of Surgery

BN1/17 B Block

London, W12 0NN, UK

\section{Nan Ma, PhD}

Universität Rostock

Klinik für Herzchirurgie and

IRMED Institut für Regenerative Medizin

Schillingallee 35

18057 Rostock, Germany

\section{Athanasios Mantalaris, PhD}

Reader in Biological Systems Engineering

Department of Chemical Engineering and Chemical Technology

Imperial College London

South Kensington Campus

Room 515, ACEX Building

London, SW7 2AZ, UK 


\section{John C. Nichols, MD}

Department of Ophthalmology

University of Arizona

1501 N. Campbell Ave.

Tucson, AZ 85724, USA

\section{Maria Notara, $\mathbf{P h D}$}

Postdoctoral Research Fellow

Cells for Sight Transplantation and Research Programme

Ocular Repair and Regeneration Biology Unit

University College London Institute of Ophthalmology

11-43 Bath Street

London, EC1V 9EL, UK

\section{Julia M. Polak, DBE, MD, DSc, FRCP, FRCPath, FMedSci, ILT}

Department of Chemical Engineering and Chemical Technology

Tissue Engineering and Regenerative Medicine Center

Imperial College London

South Kensington Campus

Room 144, Roderic Hill Building

London, SW7 2AZ, UK

\section{Wesley L. Randle, BSc (Hons), PhD}

Programme Director (Stem Cell Bioprocessing)

NovaThera Ltd

Minerva Building

Babraham Research Campus, Babraham

Cambridge, CB22 3AT, UK

\section{Nathan J. Robertson, PhD}

Sir William Dunn School of Pathology

University of Oxford

South Parks Road

Oxford, OX1 3RE, UK 


\section{Alex J. Shortt, Msc, MRCOphth}

Specialist Registrar in Ophthalmology

Moorfields Eye Hospital, London

Clinical Research Fellow

Cells for Sight Transplantation and Research Programme

University College London Institute of Ophthalmology

11-43 Bath Street

London, EC1V 9EL, UK

\section{Christof Stamm, MD}

Deutsches Herzzentrum Berlin and

Berlin-Brandenburg Center for Regenerative Therapies (BCRT)

Augustenburger Platz 1

13353 Berlin, Germany

Herman Waldmann, FRS

Sir William Dunn School of Pathology

University of Oxford

South Parks Road

Oxford, OX1 3RE, UK

\section{Claire Westwood, BSc}

Wolfson Institute for Biomedical Research

University College London

The Cruciform Building, Gower Street

London, WC1E 6BT, UK

\section{Deborah Williamson, MBBS}

Faculty of Medicine

Imperial College London

Hammersmith Hospital

Department of Neurology

St. Mary's Hospital

Praed Street, Paddington

London, W2 1NY, UK 


\section{Kathryn J. Wood, D.Phil}

Transplantation Research Immunology Group

Nuffield Department of Surgery

John Radcliffe Hospital

University of Oxford

Oxford, OX3 9DS, UK

\section{Douglas C. Wu}

Transplantation Research Immunology Group

Nuffield Department of Surgery

John Radcliffe Hospital

University of Oxford

Oxford, OX3 9DS, UK 
This page intentionally left blank 


\section{Preface}

This book is the definitive reference on one of the most exciting areas of life science research - stem cells and their use in repair and regeneration of different organs and tissues. The volume is rounded off by a set of chapters on basic stem cell biology and clinical applications and clinical experiences of stem cell therapy, considering cardiovascular disease, neurological diseases, liver disease and diabetes. These offer a sound and well-balanced view of successes to date and indications for future therapeutic routes. It presents the current state of knowledge in both basic science and clinical practice, and is an essential reference for scientists, students, and clinicians.

The editors would like to thank the authors for their contributions, which have made possible the publication of this volume. 